Jurnal Pengabdian Masyarakat

vol.1 no.1 Oktober 2017

\title{
PEMERIKSAAN, PENGOBATAN, DAN PENYULUHAN KEBERSIHAN DIRI UNTUK MENCEGAH DAN MENGOBATI KECACINGAN PADA ANAK USIA SEKOLAH GUNA MENINGKATKAN KONSENTRASI BELAJAR PADA ANAK
}

\author{
Siti Juariah $^{1)}$, Mega Pratiwi Irawan'), Mellysa Rahmita ${ }^{1)}$, Ilham Kurniati' \\ 1), Akdemi Analis Kesehatan Yayasan Fajar \\ Email. Siti.juariah1005@gmail.com
}

\begin{abstract}
Deworming is still a public health problem in Indonesia especially in areas with poor sanitation. The prevalence of worms is highest in primary school-aged children. Worm infections can cause indigestion and absorption of nutrients that result in disruption of learning and growth concentration. The target of this activity is elementary school students SDN 071 Pekanbaru class 1 and 2, which is between 6-8 years old, it is expected that children can apply personal hygiene as early as possible and make a habit. Targeted children are also expected to transmit a clean life attitude to the surrounding environment. Methods of service activities that have been done, in the first stage conducted activities of approaches to children and examination of intestinal worms in child. Results of this devotion of 30 samples performed there are children who are infected with a deworming of one person. In conclusion there are still school children who do not maintain personal hygiene and must improve their hygiene. This activity is expected to be support and guidance to the students of SD how to prevent deworming.
\end{abstract}

Key words: worm disease, children, public health

\begin{abstract}
ABSTRAK
Penyakit cacingan masih menjadi permasalahan kesehatan masyarakat di Indonesia terutama pada daerah dengan sanitasi yang buruk. Prevalensi cacingan paling tinggi terjadi pada anak usia sekolah dasar. Infeksi cacing dapat menyebabkan gangguan pencernaan dan penyerapan nutrisi yang berakibat terganggunya konsentrasi belajar dan pertumbuhan anak. Sasaran kegiatan ini adalah murid Sekolah Dasar SDN 071 Pekanbaru kelas 1 dan 2 yang berumur antara 6-8 tahun, diharapkan anak mampu menerapkan kebersihan diri sedini mungkin dan menjadikan suatu kebiasaan. Anak-anak yang menjadi sasaran juga diharapkan dapat menularkan sikap hidup bersih kepada lingkungan sekitarnya. Metode kegiatan pengabdian yang telah dilakukan, pada tahap pertama dilakukan kegiatan pendekatan terhadap anak dan pemeriksaan cacingan pada anak.hasil dari pengabdian ini dari 30 sampel yang dilakukan terdapat anak yang terinfeksi cacingan sebanyak satu orang. Kesimpulannya masih ada anak sekolah yang tidak menjaga kebersihan diri dan harus meningkatkan kebersihan dirinya. Kegiatan ini diharapkan dapat menjadi dukungan serta bimbingan kepada siswa/i SD bagaimana cara mencegah penyakit cacingan.
\end{abstract}

Kata Kunci : penyakit cacingan, anak-anak, kesehatan masyarakat 
Jurnal Pengabdian Masyarakat

vol.1 no.1 Oktober 2017

\section{PENDAHULUAN}

Sekitar 60 persen orang Indonesia mengalami infeksi cacing. Kelompok umur terbanyak adalah pada usia 5-14 stahun. Angka prevalensi sekitar 60 persen, 21 persen di antaranya menyerang anak usia SD dan rata-rata kandungan cacing per orang enam ekor. Data tersebut diperoleh melalui survei dan penelitian yang dilakukan di beberapa provinsi pada tahun 2006.

Lingkungan hidup menurut Undang-Undang nomor 23 tahun 1997 tentang Pengelolaan Lingkungan Hidup adalah kesatuan ruang dengan semua benda, daya, keadaan dan makhluk hidup, termasuk di dalamnya manusia beserta perilakunya yang mempengaruhi kelangsungan perikehidupan dan kesejahteraan manusia serta makhluk hidup lainnya. Bila ditinjau lebih lanjut mengenai.Undang-Undang tersebut, maka manusia dengan lingkungan sebenarnya tidak dapat dipisahkan. Keadaan sanitasi yang belum memadai, keadaan sosial ekonomi yang masih rendah didukung oleh iklim yang sesuai untuk pertumbuhan dan perkembangan cacing merupakan beberapa faktor penyebab tingginya prevalensi infeksi cacing usus yang ditularkan di Indonesia (Zulkoni, 2011).

Ada 3 jenis cacing yang terpenting adalah cacing gelang (Ascaris lumbricoides), cacing tambang (Ancylostoma duodenale dan Necator americanus) dan cacing cambuk (Trichuris trichura) (WHO, 2014). Ascaris lumbricoides merupakan helmintiasis yang paling sering menyerang anak-anak, cacing ini telah menyebabkan lebih dari satu milyar kasus kecacingan di seluruh dunia. Angka kejadian infeksi Ascaris lumbricoides di Indonesia sebesar $70 \pm 80 \%$, keadaan ini menyebabkan penyakit ascariasis menjadi penting dan hingga saat ini masih merupakan masalah dibidang ilmu kesehatan anak dan kesehatan masyarakat. Penyakit cacingan merupakan salah satu masalah kesehatan di Indonesia. Penyakit cacing ditularkan melalui tangan yang kotor, kuku panjang dan kotor menyebabkan telur cacing terselip.

Penyebaran cacing salah satu penyebabnya adalah kebersihan perorangan yang masih buruk. Dan dapat menular diantara murid sekolah yang sering berpegangan tangan sewaktu bermain. Sampai saat ini penyakit cacingan masih merupakan masalah kesehatan masyarakat di Indonesia, terutama daerah pedesaan. Pencegahan infeksi berulang sangat penting dengan membiasakan perilaku hidup bersih dan sehat seperti menghindari kontak dengan tanah yang kemungkinan terkontaminasi feses manusia, cuci tangan dengan sabun dan air sebelum memegang makanan, lindungi makanan dari tanah dan cuci atau panaskan makanan yang jatuh kelantai. Beberapa peneliti ternyata menunjukkan bahwa usia sekolah merupakan golongan yang sering terkena infeksi cacingan karena sering berhubungan dengan tanah (Depkes RI, 2009).

Penyakit kecacingan sangat menganggu tumbuh kembang anak. Sehingga sangat penting untuk mengenali dan mencegah penyakit cacing pada anak sejak dini. Gangguan yang ditimbulkan mulai dari yang ringan tanpa gejala hingga sampai yang berat bahkan sampai mengancam jiwa. Secara umum gangguan nutrisi atau anemia dapat terjadi pada penderita. Hal ini secara tidak langsung akan mengakibatkan gangguan kecerdasan pada anak.

\section{BAHAN DAN METODE}

Kegiatan pengabdian dilakukan pada bulan September di SDN 71 Pekanbaru.alat dan bahan yang digunakan antara lain sarung tangan, masker,pot sampel,objek glass,deck glas,mikroskop, eosin $2 \%$. Mekanisme pelaksanaan kegiatan pengabdian masyarakat ini meliputii:

\section{a. Registrasi}

Sebelum melakukan kegiatan pesert apengabdian masyarakat melakukan registrasi .kegiatan ini diikuti oleh 30 orang peserta. Kegiatan ini diikuti oleh siswa/i yang ada di SDN 71 Pekanbaru 
terutama kelas 5 dan 6 sedangkan kegiatan ini dilaksanakan oleh AAK Fajar Pekanbaru bekerjasama dengan SDN 71 Pekanbaru.

\section{b. Presentasi serta diskusi bersama peserta}

Penyampaian atau presentasi materi disampaikan oleh dosen AAK Fajar, selain itu diselasela penyampaian materi juga dilakukan diskusi bersama siswa/i tentang bagaimana cara pencegahan penyakit cacingan melalui upaya kebiasaan mencuci tangan sehingga dengan demikian siswa/i dapat terhindar dar ipenyakit cacingan.

\section{c. Pengecekan telur cacing pada feses}

Kegiatan pengabdian masyarakat ini juga dilakukan pengecekan telur cacing pada feses siswa/i SDN 71 Pekanbaru di laboratorium AAK Fajar. Kegiatan pengecekan ini dilakukan oleh siswa/i AAK Fajar yang dibantu oleh dosen AAK Fajar pekanbaru.

\section{HASIL DAN PEMBAHASAN}

Kegiatan pengabdian yang bertemakan pemeriksaan telur cacing bagi siswa/i SD di SDN 71 Pekanbaru merupakan rangkaian kegiatan pendidikan kepada siswa/i tentang bagaimana pentingnya mencegah penyakit cacingan, melalui kebiasaan mencuci tangan bagi siswa/i SD sehingga dapat mengurangi resiko penyakit cacingan tersebut. Berikut ini hasil pemeriksaan telur cacing di SDN 71 Pekanbaru.

Tabel 1. HASIL PEMERIKSAAN TELUR CACING PADA SISWA/I SDN 71 PEKANBARU

\begin{tabular}{lllll}
\hline No & Nama & Umur & Jenis kelamin & Hasil \\
\hline 1 & Riska & 11 & P & + \\
2 & Hari & 13 & L & - \\
3 & Mutafa & 11 & L & - \\
4 & Lukman & 10 & L & - \\
5 & Amir & 12 & L & - \\
6 & Fitri & 11 & P & - \\
7 & Rani & 11 & P & - \\
8 & Bachtiar & 10 & L & - \\
9 & Dewi & 10 & P & - \\
10 & Astias & 10 & P & - \\
11 & Indra & 11 & L & - \\
12 & Nur & 11 & P & - \\
13 & Anwar & 12 & L & - \\
14 & Habibah & 11 & P & - \\
15 & Silvia & 12 & P & - \\
16 & Agustin & 11 & P & - \\
17 & Putra & 10 & L & - \\
18 & Fani & 11 & P & - \\
19 & Putri & 10 & P & - \\
20 & Siska & 11 & P & - \\
21 & Arjuna & 11 & L & - \\
22 & Yanti & 11 & P & - \\
23 & Marni & 12 & P & - \\
24 & Desi & 12 & P & -
\end{tabular}


Jurnal Pengabdian Masyarakat

vol.1 no.1 Oktober 2017

\begin{tabular}{lllll}
25 & Galih & 11 & $\mathrm{~L}$ & - \\
26 & Sri & 10 & $\mathrm{P}$ & - \\
27 & Siska & 10 & $\mathrm{P}$ & - \\
28 & Faza & 11 & $\mathrm{P}$ & - \\
29 & Adriani & 12 & $\mathrm{P}$ & - \\
30 & Danu & 10 & $\mathrm{~L}$ & - \\
\hline
\end{tabular}

Dari tabel 1 maka dapat kita ketahui jumlah anak SDN 71 yang terinfeksi cacing.jumlah anak yang terinfeksi cacing sebanyak satu orang dengan jenis kelamin perempuan. Berdasarkan hasil yang telah dilaksanakan menunjukkan bahwa SDN 71 Pekanbaru masih ada yang terinfeksi cacing. Hal ini disebabkan oleh beberapa factor diantaranya ialh dari lingkungan dan pola hidup masyarakat sekitar lingkungan SDN 71 Pekabaru. Menurut Fitri (2012) Infeksi cacingan sangat mudah menyerang anak-anak karena sangat berhubungan erat dengan kebersihan diri dan kebersihan lingkungan. Beberapa penyebab infeksi cacing sebagai berikut:

a. Tidak memakai alas kaki

Larva cacing gelang dapat menembus kulit dan masuk kealiran darah, anak-anak yang tidak menggunakan alas kaki saat bermain sangat beresiko terinfeksi cacing.

b. Makanan

Makanan yang tercemar oleh larva atau telur cacing dan dimakan oleh anak akan menyebabkan cacing berkembang didalam usus.

c. BAB sembarang tempat

Anak-anak yang terinfeksi cacing akan mengeluarkan telur dan mengontaminasi tanah. Cacing akan berkembang dan menyebar ditanah.

d. Kebiasaan mencuci tangan

Menurut hasil penelitian penyebab yang paling signifikan penyebaran infeksi cacing ialah kebiasaan mencuci tangan setelah beraktifitas.

Penyakit kecacingan juga mempengaruhi kehidupan serta tingkat kesehatan dan perkembangan anak. Menurut Siregar, (2006) Infeksi cacing usus berpengaruh terhadap penyerapan nutrisi dan metabolisme makanan yang berakibat tidak cukupnya asupan protein, karbohidrat, lemak, dan vitamin yang dibutuhkan untuk perkembangan anak. Infeksi cacingan juga dapat menimbulkan ganngguan pada respon imunitas pada anak. Sehingga anak penderita infeksi cacing usus sangat rentan untuk mengalami mal nutri dan gangguan pertumbuhan.

\section{KESIMPULAN}

Berdasarkan pemeriksaan kecacingan pada anak-nak SDN 71 Pekanbaru maka dapat disimpulkan bahwa masih terdapat anak yang terinfeksi cacing walupun jum;lhanya hanya 1 orang dari 30 sampel yang dilakukan pegujian.

\section{UCAPAN TERIMAKASIH}

Pada kesematan ini kami mengucapkan erimakasih kepada Universitas Abdurrab yang telah memberikan bantuan dana pengabdian masyarakat, selain itu juga kepada Akademi Analis Kesehatan Yaysan Fajar dan SDN 71 Pekanbaru yang telah memfasilitasi kegiatan pengabdian masyarakat. 
Jurnal Pengabdian Masyarakat

vol.1 no.1 Oktober 2017

\section{DAFTAR PUSTAKA}

1. Fitri J, Saam Z, dan Hamidy M.Y,. 2012. Analisis Faktor-Faktor Risiko Infeksi Kecacingan Murid Sekolah Dasar Di Kecamatan Angkola Timur Kabupaten Tapanuli Selatan Tahun 2012. Jurnal ilmu lingkungan. ISSN 1978-5283.

2. Profil Kesehatan indonesia. 2009. Distribusi Prevalensi kecacingan pada Anak SD di kabupaten Terpilih tahun 2002-2008. Jakarta: Departemen kesehatan RI.

3. Siregar C.D,. 2012 Pengaruh Infeksi Cacing Usus yang Ditularkan Melalui Tanah pada Pertumbuhan Fisik Anak Usia Sekolah Dasar. Sari Pediatri. 112-117

4. WHO.2014.Soil-transmitted helminthes.(Online),(http://www.who.int/intestinalworms/epidemiology/en/diakses 15 september 2016).

5. Zulkoni, A.(2011). Parasitologi untuk keperawatan, kesehatan masyarakat dan teknik lingkungan,nuha medika, Yogyakarta. 